\title{
Evaluation of Antimicrobial Resistance Rates in Klebsiella Isolates
} Klebsiella Izolatlarının Antimikrobiyal Direnç Oranlarının Değerlendirilmesi

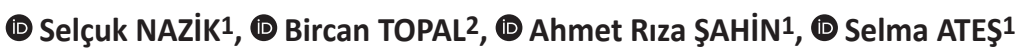 \\ ${ }^{1}$ Kahramanmaraş Sütçü Imam University Faculty of Medicine, Department of Infectious Diseases and Clinical Microbiology, Kahramanmaraş, Turkey \\ 2Kahramanmaraş Sütçü Imam University Faculty of Medicine, Infection Control Committee Nursing, Kahramanmaraş, Turkey
}

\section{Abstract}

Introduction: Bacteria of the genus Klebsiella are important causes of nosocomial infections. These bacteria may develop resistance in different ways, with extended-spectrum beta-lactamase (ESBL) production being the most common. The aim of this study was to evaluate resistance status of Klebsiella isolates obtained from different intensive care units and various clinical samples.

Materials and Methods: Resistance rates of Klebsiella spp. strains isolated from bacteriologic cultures of patients in intensive care units between 2014 and the first six months of 2017 were evaluated retrospectively. Blood, urine, bronchoalveolar lavage, cerebrospinal fluid, and tracheal aspirate samples were cultured. Intensive care patients aged $\geq 18$ years were included. Only the first isolate from each patient was included; subsequent isolates from the same patient were excluded.

Results: A total of 443 patients were included in the study. Of the Klebsiella-positive samples, 31.8\% ( $n=141)$ were tracheal aspirate, 23.7\% ( $n=105)$ were blood, 23.3\% $(n=103)$ were urine, 9.0\% $(n=40)$ were sputum, and $12.2 \%(n=54)$ were other samples. The majority of cases were $K$. pneumoniae $(89.7 \%, n=397)$, followed by . oxytoca $(7 \%, n=31), K$. ozaenae $(2.9 \%, n=13)$, K. granulomatis $(0.2 \%, n=1)$, and $K$. ornithinolytica $(0.2 \%, n=1)$. Of the 443 isolates, $54.4 \%(n=241)$ were ESBL-producing while $45.6 \%(n=202)$ were non-ESBL-producing. Mortality rates were $60 \%$ among patients with ESBL-positive Klebsiella and 47.5\% among patients with ESBL-negative Klebsiella ( $\mathrm{p}=0.008$ ).

Conclusion: The antibiotic resistance of ESBL-positive Klebsiella isolates in our hospital was higher than resistance rates in the literature. To overcome this resistance issue, each hospital must know its own resistance rates and establish policies for the rational use of antibiotics.

Keywords: Extended-spectrum beta-lactamase, Klebsiella, ciprofloxacin, colistin, tigecycline

\section{Öz}

Giriş: Klebsiella cinsi bakteriler nozokomiyal enfeksiyonların önemli bir nedenidir. Bu bakteriler farklı şekillerde direnç geliştirebilirler. Genişlemiş spektrumlu beta-laktamaz (GSBL) yapımı bunların başında gelmektedir. Bu çalışmada, farklı yoğun bakım ünitelerinden ve çeşitli klinik örneklerden elde edilen Klebsiella izolatlarının direnç durumlarının değerlendirilmesi amaçlanmıştır.

Gereç ve Yöntem: Çalışmada 2014-2017 (ilk 6 ay) tarihleri arasında yoğun bakım ünitelerinde yatan hastaların bakteriyolojik kültüründen izole edilen Klebsiella spp. kökenlerinin direnç oranları retrospektif olarak incelendi. Kan, idrar, bronkoalveolar lavaj, beyin omurilik sıvısı trakeal aspirat gibi örnekler kullanıldı. Çalışmaya $\geq 18$ yaş yoğun bakım hastaları dahil edildi. Hastalardan ilk izole edilen suş çalışmaya alınırken aynı hastaya ait mükerrer izolatlar çalışma dışı tutuldu.

Bulgular: Çalışmaya 443 olgu dahil edildi. Klebsiella izole edilen örnekler incelendiğinde \%31,8'inin (n=141) trakeal aspirat kültürü, \%23,7'sinin $(n=105)$ kan, \%23,3'ünün ( $n=103)$ idrar, \%9,0'ının $(n=40)$ balgam ve \%12,2'sinin ( $=54)$ diğer örneklerden oluştuğu tespit edilmiştir. Klebsiella türlerinin dağılımı incelendiğinde olguların büyük bir kısmını \%89,7 (n=397) ile Klebsiella pneumoniae oluşturmaktaydı. Sonrasında sırası ile K.

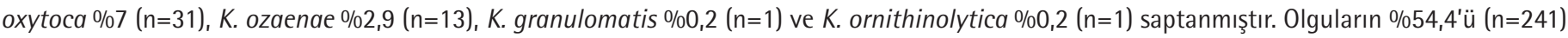
GSBL (+) iken \%45,6'sının ( $n=202$ ) GSBL (-) olduğu tespit edilmiştir. ESBL-pozitif Klebsiella enfeksiyonlu hastalarda mortalite \%60 iken, ESBL negatif kökenlere bağlılarda \%47,5 idi $(p=0,008)$.

Sonuç: Hastanemizde GSBL (+) Klebsiella izolatlarına ait antibiyotik direncinin literatürdeki direnç oranlarından daha yüksek olduğu saptanmıştır. $\mathrm{Bu}$ direnç sorununun üstesinden gelebilmek için her hastane kendi direnç oranlarını bilmeli ve akılcı antibiyotik kullanım politikaları geliştirmelidir. Anahtar Kelimeler: Genişlemiş spektrumlu beta-laktamaz, Klebsiella, siprofloksasin, kolistin, tigesiklin

Cite this article as: Nazik S, Topal B, Şahin AR, Güler S. Evaluation of Antimicrobial Resistance Rates in Klebsiella Isolates. Mediterr J Infect Microb Antimicrob. 2018;7:8. 


\section{Introduction}

Klebsiella is an important genus of the Enterobacteriaceae family which causes community-acquired infections as well as nosocomial infections ${ }^{[1]}$. Present in small amounts in normal flora, Klebsiella spp. may cause colonization and subsequent infection in cases of prolonged hospitalization, invasive procedures such as urinary or central venous catheterization, history of prior surgery, or use of broad-spectrum antibiotics ${ }^{[2,3]}$. It has been known for the last four or five decades that Gram-negative bacteria are more common causes of nosocomial infections ${ }^{[4]}$. Today, knowing the resistance pattern of the bacterial agent has become more important than knowing whether it is Gramnegative or Gram-positive.

Klebsiella bacteria may develop different mechanisms of antibiotic resistance. Among them, the most common is extended-spectrum beta-lactamase (ESBL) production ${ }^{[5]}$. Another form is carbapenem resistance ${ }^{[6]}$. Resistant bacteria lead to prolonged hospitalization, loss of labor, high costs, and high mortality.

Intensive care patients are critical patterns who require early and effective treatment. Therefore, each hospital must be aware of its specific bacterial resistance rates and initiate empirical treatment accordingly. The aim of this study was to determine the resistance profiles of Klebsiella bacteria isolated from various sample types in various clinical samples in the intensive care units (ICUs) of our setting and contribute to policies regarding the appropriate use of antibiotics.

\section{Materials and Methods}

Resistance rates of Klebsiella spp. strains isolated from clinical samples of patients residing in ICUs of the Kahramanmaraş Sütçü İmam University Faculty of Medicine between January 2014 and June 2017 were analysed retrospectively. Blood, urine, bronchoalveolar lavage, tracheal aspirate culture (TAC), cerebrospinal fluid, pleural fluid, peritoneal fluid, drainage fluid, and wound site samples were cultured. Cerebrospinal fluid, pleural fluid, peritoneal fluid, drainage fluid, and wound site samples were analysed within the category of 'others' because they were fewer in number. The study included only patients aged 18 years or older who were treated in ICUs. For patients with multiple isolates, only the first strain isolated was included in the analysis.

Clinical samples received by the microbiology laboratory were inoculated on 5\% sheep blood agar (RTA, Turkey) and EMB agar (RTA, Turkey) and incubated at $37^{\circ} \mathrm{C}$ for $18-24$ hours. Colonies showing Gram-negative bacilli in Gram staining and were identified as oxidase negative, lactose positive, and mucoid producing on culture medium were suspended at a turbidity of 0.5 McFarland. Identification and antibiotic susceptibility tests were done in accordance with "European Committee on Antimicrobial Susceptibility Testing" (EUCAST) recommendations using a Phoenix 100 (Becton Dickinson, USA) system. Extended-spectrum beta-lactamase-producing organisms were identified based on susceptibility to aztreonam, third and fourth generation cephalosporins (cefpodoxime 8 $\mu \mathrm{g} / \mathrm{mL}$, ceftazidime $8 \mu \mathrm{g} / \mathrm{mL}$ ) alone and/or in the presence of beta-lactamase inhibitors (ceftriaxone/clavulanic acid $2 \mu \mathrm{g} /$ $\mathrm{mL}$, cefotaxime/clavulanic acid $2 \mu \mathrm{g} / \mathrm{mL}$, ceftazidime/clavulanic acid $2 \mu \mathrm{g} / \mathrm{mL}$ ). Imipenem, meropenem, and ertapenem minimum inhibitor concentration values were tested and metallo-betalactamase producing strains were considered carbapenemresistant.

\section{Statistical Analysis}

SPSS v.17.0 software package (SPSS Inc, Chicago, Illinois, USA) was used in statistical analyses of the data obtained from the study. Continuous data were summarized as mean and standard deviation, while categorical data were expressed as number and percentage. Student's t-test was used in comparisons of continuous variables between independent groups. The chisquare $\left(\chi^{2}\right)$ test was used when comparing categorical values between independent groups. Statistical significance level was accepted as $p<0.05$.

\section{Results}

The mean age of the 443 patients was $66.0 \pm 20.2$ years (minimum-maximum, $19-102$ years); $56.9 \%(n=252)$ were male and $43.1 \%$ (191) were female.

Of the samples from which Klebsiella was isolated, 31.8\% $(n=141)$ were TAC, 23.7\% $(n=105)$ were blood, 23.3\% $(n=103)$ were urine, 9.0\% $(n=40)$ were sputum, and $12.2 \%(n=54)$ were other sample types.

The three most common units where Klebsiella-positive cultures were performed were the Anesthesia ICU with 56.9\% $(n=252)$, the Internal Medicine ICU with $16.9 \%(n=75)$, and the Neurology ICU with $10.4 \%(n=46)$. Data pertaining to all units are summarized in Table 1.

In terms of the distribution of Klebsiella species, Klebsiella pneumoniae accounted for the large majority of cases (89.7\%, $\mathrm{n}=397)$. This was followed by $K$. oxytoca $(7 \%, \mathrm{n}=31), K$. ozaenae $(2.9 \%, n=13)$, K. granulomatis $(0.2 \%, n=1)$, and $K$. ornithinolytica $(0.2 \%, n=1)$.

Extended-spectrum beta-lactamase-positive strains accounted for $54.4 \%(n=241)$ of the cases, while $45.6 \%(n=202)$ were ESBL-negative. 
The antibiotic susceptibility rates of the $K$. pneumoniae and $K$. oxytoca strains are presented in Table 2.

The mean duration of hospital stay was $47.04 \pm 40.7$ days (minimum-maximum, 1-220 days). Hospital stays were slightly longer in ESBL-positive cases (47.65 \pm 39.6 days) compared to ESBL-negative cases ( $46.31 \pm 42.0$ days), but the difference was not statistically significant $(p=0.729)$.

The mortality rate was $54.4 \%$ while the remaining $45.6 \%$ of the patients were discharged with full recovery. All deaths occurred at the hospital, on day $42.3 \pm 34.7$ of hospitalization. The mortality rate was $60.2 \%$ among patients with ESBL-positive Klebsiella versus $47.5 \%$ among patients with ESBL-negative Klebsiella $\left(\chi^{2}, p=0.008\right)$. In addition, the mortality rate was $55.7 \%$ among patients with carbapenem-resistant Klebsiella and $53.8 \%$ among patients with non-carbapenem-resistant
Klebsiella $\left(\chi^{2}, p=0.717\right)$. The association between culture types and patient mortality is shown in Table 3.

\section{Discussion}

Drug resistance in Gram-negative bacteria is a serious global concern. Extended-spectrum beta-lactamases are most often produced by Escherichia coli and Klebsiella spp., which are members of Enterobacteriaceae family ${ }^{[7,8]}$. Extended-spectrum beta-lactamase-producing bacteria are not only resistant to penicillin, but to many cephalosporins and monobactams as well. They may also develop resistance to other drug groups such as quinolones, tetracyclines, aminoglycosides, and carbapenems $^{[9-11]}$.

While the prevalence of ESBL-producing Klebsiella is increasing in Turkey and eastern Europe, it is on a downward trend in

Table 1. Distribution of Klebsiella isolates according to hospital unit and sample type [n (\%)]

\begin{tabular}{|c|c|c|c|c|c|c|}
\hline & Blood & Urine & TAC & Sputum & Other* & Total \\
\hline Anesthesia ICU & $77(30.6)$ & $34(13.5)$ & $93(36.9)$ & $27(10.7)$ & $21(8.3)$ & $252(100)$ \\
\hline Internal medicine ICU & $11(14.7)$ & $42(56.0)$ & $6(8.0)$ & $4(5.3)$ & $12(16.0)$ & $75(100)$ \\
\hline Neurology ICU & $4(8.7)$ & $17(37)$ & $18(39.1)$ & $1(2.2)$ & $6(13.0)$ & $46(100)$ \\
\hline Pulmonary ICU & $1(4.0)$ & $2(8.0)$ & $18(72.0)$ & $2(8.0)$ & $2(8.0)$ & $25(100)$ \\
\hline Cardiovascular surgery ICU & $0(0)$ & $0(0)$ & $1(50.0)$ & $1(50.0)$ & $0(0)$ & $2(100)$ \\
\hline Coronary ICU & $2(25.0)$ & $2(25.0)$ & $0(0)$ & $3(37.5)$ & $1(12.5)$ & $8(100)$ \\
\hline Total (n) & 105 & 103 & 141 & 40 & 54 & 443 \\
\hline
\end{tabular}

*Includes cerebrospinal fluid, pleural fluid, peritoneal fluid, drainage fluid, and wound site samples.

TAC: Tracheal aspirate culture, ICU: Intensive care unit

Table 2. Antibiotic susceptibility rates of $K$. pneumoniae and $K$. oxytoca strains

\begin{tabular}{l|c|c|c|c|c|c}
\hline \multirow{2}{*}{ Antibiotic } & \multicolumn{2}{|c|}{ K. pneumoniae [n (\%)] } & \multicolumn{4}{c}{$\begin{array}{c}\text { K. oxytoca [n (\%)] } \\
n=31\end{array}$} \\
\cline { 2 - 7 } & ESBL (+) $\mathbf{n = 2 2 6}$ & ESBL (-) n=171 & $\mathbf{p}^{*}$ & ESBL (+) n=8 & ESBL (-) n=23 & $\mathbf{p}^{*}$ \\
\hline Piperacillin/tazobactam & $144(63.7)$ & $80(46.8)$ & 0.001 & $5(62.5)$ & $6(26.1)$ & 0.064 \\
\hline Ceftriaxone & $226(100)$ & $85(49.7)$ & 0.000 & $8(100)$ & $7(30.4)$ & 0.001 \\
\hline Cefepime & $226(100)$ & $78(45.6)$ & 0.000 & $8(100)$ & $7(30.4)$ & 0.001 \\
\hline Ceftazidime & $226(100)$ & $83(48.5)$ & 0.000 & $8(100)$ & $5(21.7)$ & 0.000 \\
\hline Gentamicin & $125(55.3)$ & $70(40.9)$ & 0.005 & $1(12.5)$ & $5(21.7)$ & 0.569 \\
\hline Amikacin & $43(19.0)$ & $32(18.7)$ & 0.937 & $0(0)$ & $2(8.7)$ & 0.389 \\
\hline Ciprofloxacin & $167(73.9)$ & $74(43.3)$ & 0.000 & $3(37.5)$ & $4(17.4)$ & 0.241 \\
\hline Ertapenem & $91(40.3)$ & $53(31.0)$ & 0.057 & $1(12.5)$ & $4(17.4)$ & 0.746 \\
\hline Imipenem & $67(29.7)$ & $44(25.7)$ & 0.389 & $0(0)$ & $3(13.0)$ & 0.282 \\
\hline Meropenem & $69(30.5)$ & $43(25.1)$ & 0.238 & $0(0)$ & $3(13.0)$ & 0.282 \\
\hline TMP-SMX & $173(76.5)$ & $85(49.7)$ & 0.000 & $7(87.5)$ & $5(21.7)$ & 0.001 \\
\hline Tigecycline & $68(30.1)$ & $18(10.5)$ & 0.000 & $0(0)$ & $1(4.3)$ & 0.549 \\
\hline Colistin & $21(9.3)$ & $9(5.30)$ & 0.133 & $0(0)$ & $0(0)$ & - \\
\hline
\end{tabular}

${ }^{*}$ Chi-square test was used for intergroup comparisons. ESBL: Extended-spectrum beta-lactamase, TMP-SMX: Trimetoprim-sulfamethoxazole, $\mathrm{p}<0.05$ was considered significant 
Table 3. The relationship between culture type and mortality of cases [n (\%)]

\begin{tabular}{l|l|l|l}
\hline \multirow{2}{*}{ Culture type } & \multicolumn{2}{|l|}{ Outcome } & \multirow{2}{*}{ Total } \\
\cline { 2 - 3 } & Discharged & Death & \\
\hline Blood & $42(40.0)$ & $63(60.0)$ & $105(100)$ \\
\hline Urine & $58(56.3)$ & $45(43.7)$ & $103(100)$ \\
\hline Tracheal aspirate culture & $58(41.1)$ & $83(58.9)$ & $141(100)$ \\
\hline Sputum & $16(40.0)$ & $24(60.0)$ & $40(100)$ \\
\hline Other $^{*}$ & $28(51.9)$ & $26(48.1)$ & $54(100)$ \\
\hline
\end{tabular}

*Includes cerebrospinal fluid, pleural fluid, peritoneal fluid, drainage fluid, and wound site samples

western Europe. Antimicrobial resistance patterns may vary between regions, hospitals, and even units within the same hospital. Therefore, each hospital must know its specific antimicrobial resistance profile. Rates of ESBL-producing Klebsiella vary widely in the literature, too. Temiz et al. ${ }^{[12]}$ detected ESBL-producing Klebsiella at rates of $65.1 \%$ in samples obtained from ICUs, inpatient units, and outpatient units (68.3\% in $K$. pneumoniae isolates and $10.7 \%$ in $K$. oxytoca isolates). Parlak et al. ${ }^{[13]}$ reported ESBL-positive K. pneumoniae in 67\% of samples obtained from inpatient units and the ICU. Güdücüoğlu et al. ${ }^{[14]}$ reported this rate to be $49 \%$. In the HITIT-2 study involving 6 centers in Turkey, the prevalence of ESBL-producing K. pneumoniae was $32.3 \%$, with only $16.2 \%$ in ICUs ${ }^{[15]}$. The International Nosocomial Infection Control Consortium report for Turkey summarized data from 19 hospitals between 2003 and $2012^{[16]}$. It was determined in the study that ceftriaxoneand ceftazidime-resistant $K$. pneumoniae strains accounted for $55.7 \%$ of central catheter-related bloodstream infections, $46.3 \%$ of ventilator-associated pneumonia, and $50.0 \%$ of catheter-related urinary tract infections in the ICU. The ESBLpositive Klebsiella ratio in our study was 54.4\%.

Beta-lactam/beta-lactamase inhibitors may be preferred for infections caused by ESBL-producing bacteria. In a study by Kuzucu et al. ${ }^{[17]}, 68 \%$ of ESBL-producing K. pneumoniae isolates were found to be piperacillin/tazobactam resistant. This rate was $32 \%$ in another study ${ }^{[18]}$, and was $22.3 \%$ in the HITIT-2 study ${ }^{[15]}$. The results of our study were similar to those of Kuzucu et al. ${ }^{[17]}$. Resistance to beta-lactam/beta-lactamase inhibitors is increasing.

In severe/systemic infections caused by ESBL-producing Klebsiella spp., drugs should be chosen based on susceptibility patterns. In their 2005-2006 analysis, Güdücüoğlu et al. ${ }^{[14]}$ observed no carbapenem resistance among ESBL-positive $K$. pneumoniae isolates. There was also no resistance to carbapenem in three of the centers (Akdeniz, Hacettepe, and Dokuz Eylül Universities) involved in the multicenter HITIT-2 study conducted in 20042005. However, carbapenem resistance was detected at a rate of $1.3 \%$ in the other three centers ${ }^{[15]}$. More recently, a study by
Saygılı Pekintürk and Akgüneş ${ }^{[19]}$ reported imipenem resistance rates of $2 \%, 7 \%, 0 \%, 38 \%$, and $50 \%$ respectively in the years 2011-2015. Although numerous previous studies demonstrated carbapenem susceptibility of ESBL-positive Klebsiella isolates, current evidence shows that carbapenem resistance is becoming more prevalent among ESBL-positive Klebsiella isolates. We also found high resistance to carbapenems in the ESBL-positive K. pneumoniae strains in our study, with rates of $40.3 \%$ for ertapenem, 30.5\% for meropenem, and 29.7\% for imipenem.

In ESBL-positive infections, drugs in the quinolone group may be used as an alternative to beta-lactam/beta-lactamase inhibitors or carbapenems ${ }^{[20]}$. However, previous studies have generally reported high quinolone resistance rates. Parlak et al. ${ }^{[13]}$ determined ciprofloxacin resistance rates of $11 \%, 8 \%, 13 \%$, $35 \%$, and 36\% in ESBL-positive K. pneumoniae isolates between 2006 and 2010. In another study, the average ciprofloxacin resistance in the years 2011-2015 was 46\% (no data for 2011; $48 \%, 24 \%, 52 \%$, and $58 \%$ respectively for the remaining years) ${ }^{[19]}$. In another study by Nepal et al. ${ }^{[21]}$, ciprofloxacin resistance of ESBL-positive $K$. pneumoniae isolates was $46.2 \%$. In our study, the rate of ciprofloxacin resistance in ESBL-positive $K$. pneumoniae isolates was much higher than the rates reported in the literature.

We detected higher rates of antibiotic resistance in the ESBLpositive Klebsiella isolates in our study compared to resistance rates in the literature. This may be attributed to the fact that all of the patients included in this study were ICU patients.

\section{Conclusion}

In order to overcome the problem of resistance in ESBL-positive Klebsiella spp., each hospital should be aware of its specific resistance rates and the infection control committee should conduct regular surveillance. Units with high resistance rates should be evaluated for deficiencies, and remedial measures and training should be implemented. Furthermore, cultures and antibiotic susceptibility tests should be utilized more diligently before initiating antibiotics. Policies for the rational use of antibiotics should be established in light of this information in order to reduce resistance rates.

\section{Ethics}

Ethics Committee Approval: Retrospective study.

Informed Consent: Retrospective study.

Peer-review: Externally and internally peer-reviewed.

\section{Authorship Contributions}

Concept: S.N., S.A., Design: S.N., S.A., A.R.Ş., Data Collection or Processing: B.T., S.N., Analysis or Interpretation: S.N., A.R.Ş., 
Literature Search: S.N., A.R.Ş., Writing: S.N., S.A.

Conflict of Interest: No conflict of interest was declared by the authors.

Financial Disclosure: The authors declared that this study received no financial support.

\section{References}

1. Köseoğlu EÖ, Altun UH, Ergin A, Boral B, Şener B, Hasçelik G. Carbapenem Resistance in ESBL Positive Enterobacteriaceae Isolates Causing Invasive Infections. Mikrobiyol Bul. 2014;48:59-69.

2. Aydemir A, Yalçı A, Pişkin N, Gürbüz Y, Türkyılmaz R. The ratio of extended spectrum beta-lactamase production and antibiotic resistance in Escherichia coli and Klebsiella pneumoniae. Klimik Dergisi. 2006;19:63-8.

3. Livermore DM. Beta-lactamases in laboratory and clinical resistance. Clin Microbiol Rev 1995;8:557-84

4. Kurutepe S, Sürücüoğlu S, Gazi H, Teker A, Özbakkaloğlu B. Antibiotic Resistance Rates of Methicillin-Resistant and -Susceptible Staphylococcus aureus Strains. İnfeksiyon Derg. 2007;21:187-91.

5. Nordmann P, Naas T, Poirel L. Global spread of carbapenemase-producing Enterobacteriaceae. Emerg Infect Dis. 2011;17:1791-8.

6. Kahraman EP, Karakeçe $E$, Erdoğan $F$, Uluyurt $H$, Köroğlu $M$, Çiftci iH. The evaluation of antibiotic resistance status of Klebsiella pneumoniae. Ortadogu Medical Journal. 2017;9:12-8.

7. Gniadkowski M. Evolution and epidemiology of extended-spectrum betalactamases (ESBLs) and ESBL-producing microorganisms. Clin Microbiol Infect. 2001;7:597-608.

8. El-Baky RMA, El-Azeim NHA, Gad GFM. Prevalence of extended-spectrum beta-lactamase, AmpC Beta-lactamase, and metallo-beta-lactamase among clinical isolates of Pseudomonas aeruginosa. J Adv Biotechnol Bioeng. 2013;1:22-9.

9. Rawat D, Nair D. Extended-spectrum B-lactamases in gram negative bacteria. J Global Infect Dis. 2010;2:263-74.

10. Falagas ME, Karageorgopoulos DE. Extendedspectrum beta-lactamaseproducing organisms. J Hosp Infect. 2009;73:345-54.

11. Clinical \& Laboratory Standards Institute (CLSI). Performance Standards for Antimicrobial Susceptibility Testing, Twenty- Fourth Informational Supplement, 2013;M100-S23. Available from: http://www.facm.ucl.ac.be/
intranet/CLSI/CLSI-M100S23-susceptibility-testing-2013-no-protection. pdf

12. Temiz H, Özbek E, Vural DG, Özekinci T. Evaluation of Antimicrobial Resistance Rates of Klebsiella Isolates. Türk Mikrobiyol Cem Derg. 2015;45:68-74.

13. Parlak $M$, Çıkman $A$, Bektaş $A$, Berktaş $M$. Extended spectrum betalactamase production and antibiotic resistance in Escherichia coli and Klebsiella pneumoniae strains: five-year follow up results. Sakarya Med J. 2012;2:11-5.

14. Güdücüoğlu $H$, Baykal $S$, İzci $H$, Berktaş M. Antimicrobial Resistance of Escherichia coli and Klebsiella pneumoniae Strains that Produce Extended Spectrum Beta-lactamase. ANKEM Derg. 2007;21:155-60.

15. Gür D, Gülay Z, Akan OA, Aktaş Z, Kayacan CB, Cakici O, Eraç B, Gültekin M, Oğünç D, Söyletir G, Unal N, Uysal S. Resistance To Never Betalactams and Related ESBL Types in Gram-negative Nosocomial Isolates in Turkish Hospitals: Results of the Multicentre Hitit Study. Mikrobiyol Bul. 2008;42:537-44.

16. Leblebicioglu H, Erben $N$, Rosenthal VD, Atasay B, Erbay A, Unal S, Senol G, Willke A, Özgültekin A, Altin N, Bakir M, Oncul O, Ersöz G, Ozdemir D, Yalcin AN, Özdemir H, Yıldızdaş D, Koksal I, Aygun C, Sirmatel F, Sener A, Tuna N, Akan ÖA, Turgut H, Demiroz AP, Kendirli T, Alp E, Uzun C, Ulusoy $S$, Arman D. International Nosocomial Infection Control Consortium (INICC) national report on device-associated infection rates in 19 cities of Turkey, data summary for 2003-2012. Ann Clin Microbiol Antimicrob. 2014;13:51.

17. Kuzucu Ç, Yetkin F, Görgeç S, Ersoy Y. Investigation of the Susceptibilities of Extended-Spectrum Beta-Lactamase Producing Escherichia coli and Klebsiella spp. Strains to Ertapenem and Other Carbapenems. Mikrobiyol Bul. 2011;45:28-35.

18. Karaayak Uzun B, Güngör S, Şerifhan İlgün $M$, Özdemir R, Baran N, Yüksel Ergin Ö. The Frequency of Extended-spectrum Beta-lactamases and In-vitro Antibiotic Resistance in Escherichia coli and Klebsiella pneumoniae Strains Isolated from Blood Cultures. ANKEM Derg. 2012;26:181-6.

19. Saygılı Pekintürk N, Akgüneş A. Extended spectrum beta-lactamase production and antibiotic resistance of Escherichia coli and Klebsiella spp. isolated from hospitalized patients: data of 2011-2015. Turk Hij Den Biyol Derg. 2017;74:221-8.

20. Paterson DL. Resistance in gram-negative bacteria: Enterobacteriaceae. Am J Infect Control. 2006;34:20-8.

21. Nepal K, Pant ND, Neupane B, Belbase A, Baidhya R, Shrestha RK, Lekhak $B$, Bhatta DR, Jha B. Extended spectrum beta-lactamase and metallo betalactamase production among Escherichia coli and Klebsiella pneumoniae isolated from different clinical samples in a tertiary care hospital in Kathmandu, Nepal. Ann Clin Microbiol Antimicrob. 2017;16:62. 